\title{
CHICKEN-POX AND THE GUILLAIN BARRÉ SYNDROME
}

\author{
BY \\ R. G. WELCH \\ From the General Hospital, West Hartlepool, Durham
}

(RECEIVED FOR PUBLICATION JUNE 6, 1962)

This child developed the classical picture of the Guillain Barré syndrome, fortunately mild, whilst suffering from chicken-pox. As this appears to be an extremely unusual complication, the details of his case are here presented.

\section{Case Report}

D.H., male, age 9 years 11 months, developed chickenpox in March 1960. He had an extensive rash and showed more general illness at the outset than did his younger brother who infected him. After a week, he complained of headache and pain in his limbs and began to vomit. When he tried to get up, he cried with pain in his legs. These symptoms persisted. When seen for the first time 14 days after the onset of his illness, he was afebrile. He had neck stiffness and the Kernig sign was positive. There was some tenderness of the muscles of the left thigh, the tendon reflexes in the legs were absent apart from a very weak response in the left ankle jerk while those in the arms appeared normally brisk except for the supinator jerks which could not be elicited. Muscle power appeared normal. The right lower abdominal reflex was absent. Cranial nerve function was normal, there was no nystagmus and both sensation and co-ordination appeared normal. He was admitted to hospital (March 29, 1960), and lumbar puncture produced a clear fluid under normal pressure, containing two white cells (both lymphocytes) per c.mm., an excess of globulin, protein $240 \mathrm{mg} . / 100 \mathrm{ml}$., chloride $760 \mathrm{mg} . / 100 \mathrm{ml}$., sugar $75 \mathrm{mg} . / 100 \mathrm{ml}$., and gold curve 0110000000 . Blood count-haemoglobin $97 \%$, white count $6,400 /$ c.mm. (50\% neutrophil, $2 \%$ eosinophil, $2 \%$ basophil polymorphonuclears, $43 \%$ lymphocytes and 3\% monocytes). Sedimentation rate (Wintrobe) $20 \mathrm{~mm}$. in one hour, P.C.V. $42 \%$. Urine was normal and Heaf test was negative. He was given soluble aspirin as his only therapy, and for the next nine days, during which time his temperature rose slightly above normal on only two occasions, his condition was watched. The neck stiffness persisted, lessening after a week; the Kernig sign remained positive. All abdominal reflexes disappeared. The tendon reflexes in the arms became more difficult to elicit and less brisk, but in the triceps and biceps never completely disappeared. The knee jerks and right ankle jerk could never be elicited but an inconstant and occasional flicker could be observed in the left. Wasting of the leg muscles became apparent and the power became weaker. Plantar responses were flexor or equivocal. Some muscle tenderness and pain were complained of in the left deltoid and biceps muscles on one occasion. No sensory changes were apparent to testing and, though he became severely constipated in the first few days in hospital, there were no signs of sphincter disturbance. There was a slight improvement in his general well-being after three or four days. A second lumbar puncture was carried out on April 6, 1960, and showed 4 cells/c.mm., all lymphocytes, globulin excess, protein $500 \mathrm{mg} . / 100 \mathrm{ml}$., chloride $720 \mathrm{mg}$./ $100 \mathrm{ml}$., sugar $45 \mathrm{mg} . / 100 \mathrm{ml}$., Lange 0000012210, Wassermann reaction negative. Next day he was given his first dose of methyl prednisolone ('medrone'), $4 \mathrm{mg}$., continuing this four-hourly for six days and then reducing to eight-hourly for six days, 12-hourly for eight days and then $2 \mathrm{mg}$. eight-hourly for a week, 12hourly for a week and daily for four days. The neck stiffness and positive Kernig sign disappeared within 36 hours of starting treatment and the child became much better. Weak tendon reflexes in knees and ankles were obtained after 12 days, the abdominal responses were likewise discovered to be present on that day, and a week later all tendon and skin reflexes appeared normal. Muscle power returned rapidly and he was allowed up after a month. Further lumbar punctures showed the following:

On April 20, 1960, 1 cell/c.mm., protein $140 \mathrm{mg} . /$ $100 \mathrm{ml}$., and globulin in excess; on May 2, 1960, 1 cell/ c.mm., protein $40 \mathrm{mg} . / 100 \mathrm{ml}$, globulin in slight excess; and on May 19, 1 cell $/ \mathrm{c} . \mathrm{mm}$., protein $40 \mathrm{mg} . / 100 \mathrm{ml}$, and globulin no excess.

Apart from a slight irritative reaction after the last lumbar puncture (headache and vomiting) and later some angular stomatitis, there was no further trouble and he was discharged well on June 4, 1960. When last seen on July 15, 1960, he was well but was said to get a little tired after walking two or three miles.

\section{Discussion}

The nature of this condition and its place as a diagnostic entity is still under dispute. In an extensive historical and clinico-pathological survey Haymaker and Kernohan (1949), having shown how Guillain modified slightly the original strict criteria 
for the diagnosis of the syndrome during the subsequent 20 years, concluded that this syndrome and that of Landry, acute ascending paralysis, were but variants of a single common entity for which they suggested the title of the Landry-Guillain-Barré syndrome of polyradiculoneuronitis. Jackson, Miller and Schapira (1957) accept the identity of the two conditions but emphasize the non-specific nature of the syndrome, its relation to other inflammatory diseases of the nervous system and elsewhere and possibly to allergy, and its response to the corticosteroid class of drugs, all of which suggest that the condition is not due to primary infection of the nervous system but to an allergy or hypersensitivity reaction. The title of post-infective neuropathy or polyradiculoneuropathy would, therefore, be preferable (Lancet, 1960). If one is to use such an eponymous title as the Guillain-Barré syndrome, it seems right and proper to reserve it for those cases which fit the picture as originally described. Osler and Sidell (1960) list 12 criteria for diagnosis, based upon those laid down by Guillain, Barré and Strohl in 1916. This child fulfils them. There is general agreement that, though it should be raised, the level of the protein in the cerebrospinal fluid depends largely on the stage of the illness when it was examined and the original critical level of $200 \mathrm{mg}$. $/ 100 \mathrm{ml}$. can be disregarded.

A preceding history of infection is not infrequent in this condition and, though this is most often a non-specific upper respiratory tract infection, it is well known that the various exanthemata of childhood may precede the nervous illness. Debré and Thieffry (1951) recorded 32 cases amongst children they had seen during a period of 14 years (23 within five years); 13 had had a preceding febrile illness, one child with measles. A 12-year-old girl developed symptoms 14 days after the onset of rubella (Osler and Sidell, 1960). Bourne and Scott (1952) reported another child, a $5 \frac{1}{2}$-year-old boy, who developed the first symptoms 11 days after the onset of measles, and Roseman and Aring (1941) reported another case in a 7-year-old girl after the same interval. It can follow smallpox vaccination (Kisch, 1958) or infective mononucleosis (Haymaker and Kernohan, 1949).

When chicken-pox affects the nervous system, it produces most often an encephalitis, often with signs of cerebellar dysfunction. Underwood (1935) found this in just over half of 132 reported instances of neurological complications of chicken-pox. Levin (1960) calculates that each year perhaps one in a million population gets a cerebellar ataxia following chicken-pox, the overall incidence of encephalitis in chicken-pox being between 1 in 6,000 and 1 in 10,000 cases. References to this particular type of complication appear uncommon. Underwood classified six cases in his review as examples of peripheral neuritis and gave details of two more in an addendum, but there are insufficient details to enable one to make a firm diagnosis of the GuillainBarré syndrome. Roseman and Aring (1941) mentioned a 4-year-old white boy whose symptoms became apparent 15 days after the onset of his chicken-pox, and a 22-year-old male negro where symptoms appeared after 22 days. Both had facial and palatal palsies and made good recoveries. Lamy, Aussannaire, Nick and Jammet (1952) reported a 6-year-old boy who developed muscle weakness on the sixth day, his symptomatology resembling that of a myopathy, but in whom in addition there was a degree of ataxia, suggesting some cerebellar involvement, though there was no nystagmus. He had a slight rise in the cerebrospinal fluid protein and cell count and though his symptoms disappeared after six weeks (he was treated with aureomycin and aneurine), absence of the tendon reflexes in the limbs was still present 10 weeks after the onset of the illness. Pathy (1955) reported a 21-year-old woman who developed vomiting and diplopia due to paralysis of the sixth cranial nerve 12 days after the rash. She also lost her knee and ankle tendon jerks and developed a coarse tremor of the outstretched hands. Her cerebrospinal fluid showed a normal cell count and a protein rise to $110 \mathrm{mg}$./ $100 \mathrm{ml}$. Five weeks after the onset of the chickenpox, the tendon jerks began to return, being normal after eight weeks when her eye began to recover, though this latter was not fully recovered until a year after the onset. The next year Heywood and Richardson (1956) reported the story of a 28-year-old woman who became unsteady on the sixth day after the onset of chicken-pox and who then developed an extreme ataxia in the absence of other cerebellar symptoms, a profound loss of kinaesthetic sense in the limbs and later some loss of vibration sense, a peripheral hyperalgesia and muscle tenderness. All deep tendon reflexes and the abdominal reflexes were lost. After nearly two years, she was still ataxic and had no tendon reflexes or vibration sense. They considered this to be a polyradiculoneuritis with the predominant pathological lesion confined to the posterior sensory nerve root and sensory fibres in the muscles. There were possibly further changes in the sensory ganglia and posterior columns of the spinal cord. They were impressed by the resemblance of the syndrome to cerebellar ataxia and suggested that some of the cases of cerebellar ataxia reported might represent 
in fact a sensory neuropathy in association with varicella. In the case reported by Clément and Kételbant (1938), the position was reversed. Their patient, a $2 \frac{1}{2}$-year-old girl, developed chicken-pox 13 days after the symptoms of the neuropathy became apparent and recovered rapidly. This may well have been a pure coincidence.

The place of the steroid group of drugs in the therapy of this condition is now well recognized. Jackson et al. (1957) and Graveson (1957) have reported favourably on its use. In this case, there was very little change to be seen during nine days' observation in the ward and a rapid improvement was apparent after starting the drug. However, the prognosis in this disease is usually good and recovery starts about three weeks to a month after the onset so one can but store away the clinical impression that this child benefited from his methyl prednisolone.

\section{Summary}

A classical example of the Guillain-Barré syndrome following chicken-pox is reported. This is an unusual complication and the literature is reviewed briefly. Some benefit appears to have been derived from the use of methyl prednisolone.

\section{REFERENCES}

Bourne, I. B. and Scott, R. B. (1952). Guillain-Barré syndrome: report of case following measles. Arch. Pediat., 69, 1.

Clément, M. and Kételbant (1938). Syndrome de Guillain et Barré et varicelle chez un enfant. J. belge Neurol. Psychiat., 38, 240 .

Debré, R. and Thieffry, S. (1951). Remarques sur le syndrome de Guillain Barré chez l'enfant. Arch. franc. Pédiat., 8, 357.

Graveson, G. S. (1957). Acute polyneuritis treated with cortisone. Lancet, 1, 340.

Haymaker, W. and Kernohan, J. W. (1949). The Landry-GuillainBarré syndrome. Medicine (Baltimore), 28, 59.

Heywood, P. M. and Richardson, J. C. (1956). Sensory neuropathy following chickenpox. Canad. med. Ass. J., 74, 903.

Jackson, R. H., Miller, H. and Schapira, K. (1957). Polyradiculitis (Landry-Guillain-Barré syndrome). Treatment with cortisone and corticotrophin. Brit. med. J., 1, 480.

Kisch, A. L. (1958). Guillain-Barré syndrome following smallpox vaccination. New Engl. J. Med., 258, 83.

Lamy, M., Aussannaire, M., Nick, J. and Jammet, M. L. (1952). Polyradiculonévrite varicelleuse à forme pseudo-myopathique. Arch. franc. Pédiat., 9.976.

Lancet (1960). Annotation. Diagnosis of Guillain-Barré syndrome. $2,84$.

Levin, S. (1960). Cerebellar ataxia following chicken-pox. Lancet, 1, 1222.

Osler, L. D. and Sidell, A. D. (1960). The Guillain-Barré syndrome - the need for exact diagnostic criteria. New Engl. J. Med., $262,964$.

Pathy, M. S. (1955). Varicella with neurological complications in an adult. Brit. med. J., 1, 1324.

Roseman, E. and Aring, C. D. (1941). Infectious polyneuritis. Medicine (Baltimore), $20,463$.

Underwood, E. A. (1935). Neurological complications of varicella. Brit. J. Child. Dis., 32, 83, 177, 241. 